AperTO - Archivio Istituzionale Open Access dell'Università di Torino

Popular education: rights and duties. School reforms in the Sardinian Kingdom between 18th and 19th centuries

This is a pre print version of the following article:

Original Citation:

Availability:

This version is available http://hdl.handle.net/2318/94972

since 2016-01-29T10:27:16Z

Published version:

DOI:10.1080/00309230.2011.560857

Terms of use:

Open Access

Anyone can freely access the full text of works made available as "Open Access". Works made available under a Creative Commons license can be used according to the terms and conditions of said license. Use of all other works requires consent of the right holder (author or publisher) if not exempted from copyright protection by the applicable law. 


\section{Article Proofs Cover Sheet}

\begin{tabular}{|l|l|l|l|}
\hline Journal acronym & CPDH & Author name & \\
\hline Volume/Issue & & Manuscript number & 560857 \\
\hline
\end{tabular}

AUTHOR: Please find attached a copy of the proofs of your article. These have been copyedited and now require your attention. When reviewing your proofs you should:

Answer all queries raised during the editing of your manuscript (see below).

Check for any other factual corrections (NB - only minor changes can be made at this stage; major revisions cannot be accepted).

All required corrections should be submitted using the CATS online corrections form. Once you have added ALL query answers and corrections, please press the SUBMIT button.

PLEASE NOTE THAT ONCE YOUR CORRECTIONS HAVE BEEN ADDED TO THE ARTICLE, IT WILL BE CONSIDERED READY FOR PUBLICATION.

\begin{tabular}{|l|l|}
\hline QUERY NO. & \multicolumn{1}{c|}{ QUERY DETAILS } \\
\hline $\begin{array}{l}\text { Queneral } 1 \\
\text { Query }\end{array}$ & $\begin{array}{l}\text { As an author you are required to secure permission if you want to } \\
\text { reproduce any copyrighted material in your article. For further details, } \\
\text { please visit http://journalauthors.tandf.co.uk/preparation/permission.asp. } \\
\text { Please confirm that: } \\
\text { permission has been sought and granted to reproduce the material in } \\
\text { both print and online editions of the journal; and } \\
\text { any required acknowledgements have been included to reflect this. }\end{array}$ \\
$\mathbf{1}$ & $\begin{array}{l}\text { Please confirm that all affiliation details for all authors are present and } \\
\text { correct. Please note that with the exception of typographical } \\
\text { errors/missing information, we are unable to make changes to authors or } \\
\text { affiliations. For clarification, please see } \\
\text { http://journalauthors.tandf.co.uk/preparation/writing.asp }\end{array}$ \\
$\begin{array}{l}\mathbf{3} 2 \\
\mathbf{3}\end{array}$ & $\begin{array}{l}\text { Are you speaking only of education for boys? If not, please change to } \\
\text { him/her, his/her in this sentence or use the plural 'children' followed by } \\
\text { 'their' } \\
\text { Please clarify what you means by the 'goods' of the colleges - do you in } \\
\text { fact mean the colleges themselves, i.e. the buildings and their contents? } \\
\text { “criticised Rousseau on many occasions, accusing him of having } \\
\text { preferred the so-called "domestic" education to public education, made } \\
\text { into the colleges" - when you say 'made into the colleges', do you mean }\end{array}$ \\
\hline
\end{tabular}




\begin{tabular}{|l|l|}
\hline 4 & $\begin{array}{l}\text { "public education, which took place in the colleges"? Please check and } \\
\text { confirm } \\
\text { "Not only did Napoleon take no interest in fostering citizens involved in } \\
\text { the life of the state, but also in the diffusion of primary school" - I think } \\
\text { the sense you are trying to convey is "Not only did Napoleon take no } \\
\text { interest in fostering citizens involved in the life of the state, but neither } \\
\text { did he concern himself with the diffusion of primary school" - i.e. he } \\
\text { was not interested in either of these things - is this correct? } \\
\text { Please provide brief biographical details for Notes on contributor }\end{array}$ \\
\end{tabular}




\title{
Popular education - rights and duties: school reforms in the Sardinian Kingdom between the eighteenth and nineteenth centuries
}

Paolo Bianchini*

Dipartimento di Scienze dell'Educazione, Università di Torino, Turin, Italy

(Received; final version received)

\begin{abstract}
Between the eighteenth and nineteenth centuries a new method for the provision of popular education emerged in Europe. The Sardinian Kingdom represents a good example of this evolution: in 1729, Piedmont was the first state in Europe to launch a "modern" educational policy with the creation of a public school system. Education was considered a concession granted by the King to deserving subjects who demonstrated the possession of pure morals and faith in Catholicism. The French Revolution imported the idea of education as a right for all citizens and made genuine attempts to reform the school, but it lacked sufficient time to build a new school system. In the following years Napoleon, who had no interest in popular education, tried to use the school to transform the inhabitants of Piedmont into French citizens, but schooling in Piedmont managed to preserve some of its own peculiarities. In 1814, when the Savoy monarchy was restored, it did not remove the French educational system, but tried to change it for its own aims. Nevertheless, Savoy gave much more attention to popular education and attempted to oblige all citizens to attend primary school. The history of the last decades had shown the importance of education in fostering loyal subjects. At the beginning of the nineteenth century it was clear that the message of the Enlightenment, which promoted the school as a way to achieve private and public happiness, had been distorted: in the following centuries education would be considered a duty rather than a right.
\end{abstract}

Keywords: popular education; right; duty; happiness; citizens

\section{The Piedmontese exception: the reforms of Victor Amadeus II}

In the second half of the eighteenth century intense debate on the goals and the methods of education rose throughout Europe, which shook public opinion everywhere, since people were becoming very aware of changes related to the education and the upbringing of their children. At least three factors of a philosophical and political nature, rather than of a pedagogic one, contributed to feeding the discussion. The first was the progressive achievement of a different concept of the internal mental processes of man: the original studies into the origins of ideas made by John Locke (An Essay Concerning Human Understanding, 1690), David Hume (Philosophical Essays concerning Human Understanding, 1748), Etienne Bonnot de Condillac (Essai sur l'origine des connaissances humaines, 1746; Traité des sensations, 1754) and

*Email: paolo.bianchini@unito.it 
Denis Diderot (Lettre sur les aveugles, 1749) freed human sciences from the innatism and placed the source of knowledge in experience and in the cognitive faculties of the individual.

This new perspective on the human mind offered education new and unexpected possibilities: born without any knowledge, but endowed with senses and the learning skills, the subject needs first of all to learn to use them in the best way. Childhood became then the object of new attentions and guardianship by families, because it was no longer considered as tainted by original sin, but as an essential moment for the construction of the person. From then on, the full realisation of the human being from the tenderest age was regarded as a necessary requisite for the attainment of "public happiness". Moreover, through Europe teaching methods and contents were harshly criticised, as they appeared less and less suitable to the needs and abilities of students.

The second factor is represented by discoveries in the medical field. Thanks to the theories of scientists of international fame such as Simon André Tissot, Jacques Ballexerd, Gerard Van Swieten and Herman Boerhaave, "children's medicine", ancestor of paediatrics, redefined the features of childhood and gave further impulse to research, inspired by empiricism, into man and his learning skills. A new branch of education was born, "physical education", with specific and deep attention to hygienic and paediatric practices, essential for the maintenance and the development of children. ${ }^{1}$

Men of letters, teachers, churchmen and above all physicians tried to spread the new discoveries on the harmful practice of wet-nursing and of other traditional practices in paediatrics (i.e. the use of rigid bandaging for the containment of the children) and, on the contrary, to promote maternal nursing. At that time, in fact, it was well known that the guardianship of children's health represented the best guarantee of their survival and growth, as well as the basis of every other form of education.

The third factor that contributed to focusing attention on educational topics was the claim laid on schooling, and especially on colleges, by the majority of European monarchies. What really interested the absolutist states was not the renewal of didactics or pedagogic models, criticised by the experts as inadequate, but the withdrawal of control from the hands of the religious orders, with obvious ideological and political implications.

For that reason, the secular agreement between state and church in the management of schools lost its strength. The expulsion of the Jesuits from the Bourbon kingdoms and their suppression by Pope Clement XIV in 1773 definitively undermined the accord. When the most important and numerous teaching order left the stage, the states had the occasion to promote a general reflection on the management of the school system, on which they could finally put their hands. ${ }^{2}$

\footnotetext{
${ }^{1}$ On medicine in the eighteenth century see Sergio Moravia, La scienza dell'uomo nel Settecento (Bari: Laterza, 1977); Elena Brambilla, "La medicina del Settecento: dal monopolio dogmatico alla professione scientifica," in Storia d'Italia, Annali 7 (Turin: Einaudi, 1984), 5-147; Marie Mulvey Roberts and Roy Porter, Literature and Medicine During the Eighteenth Century (London and New York: Wellcome Institute series in the history of medicine, 1993).

${ }^{2}$ For which see Antonio Trampus, I gesuiti e l'Illuminismo. Politica e religione in Austria e nell'Europa centrale (1773-1798) (Florence: Olschki, 2000); Paolo Bianchini, Morte e resurrezione di un Ordine religioso. La Compagnia di Gesù durante la soppressione (17591814) (Milan: Vita \& Pensiero, 2006).
} 
The reforms of the scholastic systems of Austria, Brandenburg-Prussia, France and Russia were made in those years and, at the same time, some of the masterpieces of educational literature were published, for example Rousseau's Emile (published in 1762, while the Jesuits were banned from the Kingdom of Louis XV), Lienhard und Gertrud by Pestalozzi (1781-1787), De l'homme et de son éducation by Helvétius (1773), and the fourth volume of the Scienza della Legislazione, dedicated by its author Gaetano Filangieri to the Leggi che riguardano l'educazione, i costumi e l'istruzione pubblica (1785).

These books are interesting not only for their pedagogic content, but also because they contained poorly hidden political messages: bringing the reflections of the late European Enlightenment to extreme consequences, education became the field of political utopia, in which even non-radical thinkers such as Rousseau and Filangieri could imagine a society in which all the citizens enjoyed the same opportunities from birth, starting in school.

"Educate" took on a new meaning in this literature: it was no longer a synonym for moralising, for teaching good morals, for making individuals accept the social role coherent with their family origins; it meant, instead, improving the resources of the AQ1 subject, granting him the possibility to choose his own way, training a critical member of the public opinion. These new educational ideals also promoted literacy for everyone, presenting school implicitly as the best way to obtain equal social, economic and political opportunities for everybody.

In this context, the kingdom of Savoy seems to have been merely grazed by such debates and by the reforms undertaken in other countries. In fact, the Savoyard state was the first state in Europe to launch a "modern" educational policy through the creation of a public school system and strict control over the ecclesiastical institutions. The reform was carried out between 1720 and 1729 by King Victor Amadeus II, who established the University of Turin at the top of the Piedmontese school system, with the role of controller of all the other school levels. ${ }^{3}$

Despite the opposition of the municipalities, of the local potentates and above all

AQ2 of the religious orders, the state succeeded in regaining possession of the goods of the colleges. This operation attracted great interest in the educational policies of Victor Amadeus II, who was able to establish, 30 years before the other European countries, an extensive network of secondary schools directly managed or tightly checked by the state.

\section{Pedagogy and politics in the eighteenth-century Sardinian Kingdom}

Throughout the eighteenth century, the scholastic system of the Savoyard state was taken as a model and term of comparison in Italy and in foreign countries, and questioning it became very difficult. The only subject that could be debated in the following years was didactics. Teaching methods were considered a technical problem and a neutral theme, politically acceptable because they did not implicate a general reform

\footnotetext{
${ }^{3}$ On the school system of the Savoyard State see Marina Roggero, Il sapere e la virtù. Stato, Università e professioni nel Piemonte tra Settecento e Ottocento (Turin: Deputazione Subalpina di Storia Patria, 1987); Marina Roggero., Scuola e riforme nello stato sabaudo, L'istruzione secondaria dalla Ratio Studiorum alle costituzioni del 1772 (Turin: Deputazione Subalpina di Storia Patria, 1982).
} 
of the school or a reflection on the civic and cultural goals of education, but only its daily management.

In the field of education the reforms of Victor Amadeus II had surpassed the radical overhaul of government institutions undertaken by contemporary rulers, such as Louis XIV in France, Peter I in Russia, Karl XI and XII in Sweden or Frederick William I in Brandenburg-Prussia.

In fact, the reasons for the immobility of the Piedmontese school system were essentially of two types. The first was the reform itself carried out by Victor Amadeus II, trying to introduce into all the schools in the kingdom a "perfect uniformity of useful teachings" in reality, the Savoyard king had greatly reduced their autonomy. With the purpose of taking education away from the Jesuits, he submitted it to the Magistrato della Riforma, an officer charged with control over all school levels, from the university to primary schools (with the only exception being the seminaries). Moreover, although teachers were still found for the most part amongst the clergy, the Faculty of Arts was created expressly to train a homogeneous and loyal teaching staff to which to submit the running of the colleges.

If, on the one hand, the Magistrato della Riforma assured homogeneity and order in the school system, on the other he was also charged with watching over the "orthodoxy" of teachers and pupils, not only in the religious field, but also in the political and ideological senses. Victor Amadeus II's reforms had definitely not been dictated by the wish to secularise the school system, but with the purpose of exploiting the jurisdictional controversy with Rome to strengthen monarchic absolutism.

The Constitutions for the University of 1729 submitted cultural and political control over the school to the state, shifting to the Church the moral and religious power. The real aim was to increase the influence of the monarchy on the training of its subjects, bypassing the intervention of the Jesuits and of the other teaching orders.

The second reason for the immobility of the Piedmontese school was the ending of the reforming capability of the state, well rendered in the second half of the eighteenth century. Whilst more or less all the governments in Europe were trying to reorganise their school systems (often pressurised by the suppression of the Jesuits) the Savoy Kingdom defended its school.

After the great reforms of Victor Amadeus II a progressive intellectual and political closure overcame Piedmont, involving the educational system. The new Constitutions for the University of 1772 were characterised by the total absence of meaningful provisions and did not introduce any change into school organisation. They confirmed that education was considered as a concession granted by the King to deserving subjects only when they demonstrated the possession of pure morals and faith in Catholicism. For that reason, the Constitutions underlined that "the University will ban the rascals, the perjurors, the immoral individuals, the gamblers and all those students who, disrespectful or with a pertinacious spirit, will not give certain proof of correction". 4

At the same time, the Savoyard state did not have an original idea of citizenship in that period, which is why a good Christian was immediately considered a good citizen and religion constituted the most important part of civic education for the pupils. 45 The new Constitutions pointed out that the "foundation and basis of true wisdom is the holy fear of God and the veracious cult of religion". 5 Therefore, the legislator

\footnotetext{
${ }^{4}$ Costituzioni di Sua Maestà per l'Università di Torino (Turin: Stamperia Reale, 1772), 44.

${ }^{5}$ Costituzioni di Sua Maestà per l'Università di Torino (Turin: Stamperia Reale, 1772), 47.
} 
committed himself "mainly in the Christian education of the young people, to engrave in time in their juvenile minds the pure affection for religion, without which even the most sublime knowledge could be not only useless, but also pernicious". ${ }^{6}$

In this context, educationists contributed to the defence of the state and of its school system by harshly criticising the pedagogic theories of the Enlightenment, whilst censorship carefully blocked all books considered "dangerous", including some of the educational bestsellers of the century: a long list of volumes intercepted by the Savoyard censors before 1789 contained Rousseau's Emile, catalogued amongst "erroneous books" with many works by Voltaire, and the educational texts of Helvétius, considered "antigovernment, innovatory and revolutionary".

While censorship tried at least formally to keep beyond its national borders the theories of the Enlightenment, inside the Savoyard state the official pedagogy clearly had a conservative matrix. The best example is the book by Sigismondo Gerdil, Reflexions sur la théorie et la pratique de l'éducation contre les principes de J.-J. Rousseau, which was highly successful in Europe and was translated into many languages in the following decades, becoming famous under the title Anti-Emile. ${ }^{8}$

In the following years the Barnabite Gerdil became cardinal and had important responsibilities within the congregation of Index, in Rome. In Piedmont he was considered an authority in the educational and cultural fields: a teacher at the college of Casale Monferrato, preceptor to the Prince of Piedmont, afterwards Charles Emmanuel IV, secretary of the Academy of Sciences, and finally professor at Turin University, he was one of the state's most important intellectuals. ${ }^{9}$

Gerdil was not alone in the Savoyard state: all the pedagogic literature of the period was very conservative. The other authority appreciated in the pedagogic field shared the same ideas. Count Robbio of St Raffaele, an esteemed man of letters, belonged to the secret society of Catholic inspiration Amicizia cattolica, whose objective was to contain the diffusion of the values of the Enlightenment through the publishing and the dissemination of "good books". 10

For Robbio the cultural and pedagogic engagement consisted essentially in the confutation of the educational principles of Enlightenment. ${ }^{11}$ The very few authors who did not agree with the official pedagogy, for example Carlo Denina, Pier

\footnotetext{
${ }^{6}$ Regolamenti del Magistrato della riforma annessi alle Costituzioni di sua maestà, 1772 (Turin: Stamperia Reale, 1772), 1-2.

${ }^{7}$ Archivio di Stato di Torino, Sezione Prima, Regia Università, Mazzo 7, fascicolo 6, Verbali diversi di ricognizione, di sigillamento, e di assicurazione di tutti gli effetti appartenuti alla Regia Università, Museo, Biblioteca, e Cappella annesse, a cui si è proceduto dall'Intendente Racagni deputato dal Presidente Capo dei Regi Archivi di Corte dipendentemente dagli ordini della Segreteria di Stato per gli affari interni, 1 October 1799.

${ }^{8}$ Sigismondo Gerdil, Réflexions sur la théorie et la pratique de l'éducation contre les principes de M. Rousseau (Turin: Reycends \& Guibert, 1763).

${ }^{9}$ About Gerdil see Roberto Valabrega, Un anti-illuminista dalla cattedra alla porpora. Giacinto Sigismondo Gerdil professore, precettore a corte e cardinale (Turin: Deputazione subalpina di storia patria, 2004); A. Bianchi, L'istruzione secondaria tra barocco ed età dei lumi. Il collegio di San Giovanni alle Vigne di Lodi e l'esperienza pedagogica dei Barnabiti (Milan: Vita e Pensiero, Pubblicazioni dell'Università Cattolica, 1993).

${ }^{10}$ Candido Bona, Le "Amicizie," Società segrete e rinascita religiosa (1770-1830) (Turin: Deputazione Subalpina di Storia Patria, 1962), 38-53.

${ }^{11}$ Benvenuto Robbio di San Raffaele, Della educazione continuata (Turin: Stamperia Fontana, 1783); Benvenuto Robbio di San Raffaele, Apparecchio degli educatori del conte di San Raffaele (Turin: Mairesse, 1787).
} 
Domenico Soresi or Paolo Maria Paciaudi, were obliged to emigrate to spread their ideas.

The point of view of the late Enlightenment, which considered education as the utopia and the only way to change the world, was rejected. The ideas of the philosophes were able to circulate in Piedmont thanks to the few journals permitted for a short time by the authorities. Particularly between 1787 and 1789, the "Biblioteca Oltremontana" was the most interested in education. A periodical, edited by the brothers Giambattista and Francis Dalmazzo Vasco, it devoted many articles to the review of books proposing innovations in pedagogy, didactics and paediatrics. ${ }^{12}$

At the same time the journal defended with conviction the state school, not because the publishers were contrary to the reforms, but to oppose private and individual education, which was ruled by families. For that reason the "Biblioteca Oltremontana" criticised Rousseau on many occasions, accusing him of having preferred the so-called "domestic" education to public education, made into the colleges.

The journal was short lived: in 1789, the Savoyard state strengthened censorship and the Vasco brothers were forced to resign. While the new editors assumed a more moderate publishing line, Francis Dalmazzo was jailed for subversive activity and Giambattista was forced into silence.

This was only the beginning. In 1792, as soon it was realised that the example of revolutionary France could be imitated in Piedmont, the government immediately rushed to close the university and the College of the Provinces (the school founded by Victor Amadeus II for poor but deserving students), the most important and representative cultural institutions of the Kingdom, in fear of the contribution that the students might make to the diffusion of the "new ideas of France".

As always in the past, during wars or in situations of political tension with a foreign country, the Piedmontese government closed the university and the secondary schools. It was clear, then, that the Savoyard state had maintained its own inveterate distrust of culture, intended as a form of patrimony to be exclusively permitted to teachers and pupils of tested rectitude.

\section{French occupation}

Both institutions remained closed until the Savoy household left their Kingdom. When the French Army entered Turin at the end of 1798, one of the first decisions of the Republican government was specifically to reopen the schools. The event assumed a very clear symbolic meaning, because it was part of the educational and political strategy of the new government, which promoted education as a right for everyone.

At the top of the school system was a Jury d'instruction publique, composed of a triumvirate: Sebastiano Giraud, a doctor and one of the most representative members of the Piedmontese Freemasonry and of the Bavarian Illuminati; Carlo Botta, another physician and freemason, who was to become famous in the following years for his historical works; and Francesco Brayda, former professor of Law at the University of Cagliari in Sardinia, and defence attorney of the poor.

\footnotetext{
$\overline{{ }^{12} \text { Franco Venturi, Riformatori lombardi, piemontesi e toscani, vol. } 3 \text { of Illuministi Italiani, }}$ ed. Franco Venturi (Milan and Naples: Ricciardi, 1958); Gianni Marocco, Giambattista Vasco (Turin: Fondazione Luigi Einaudi, 1978); Silvia Rota Ghibaudi, Dalmazzo Francesco Vasco, Opere (Turin: Fondazione Luigi Einaudi, 1966); Giambattista Vasco. Opere, 2 vols. Ed. Maria Luisa Perna (Turin: Fondazione Luigi Einaudi, 1989-1992).
} 
They were all staunch supporters of the French Revolution and of the Republic. Between 1800 and 1802, they tried to fit the Piedmontese school to the ideas promoted by the Republican government. In those three years, the Jury was particularly free because Jean-Baptiste Jourdan, General Administrator of the $27^{\text {th }}$ Military Division (this was the name assumed by the former Savoyard state) supported its work. Jourdan was sincerely interested in reforming the school. For that reason he called on a new secretary from France, Pierre Toussaint de La Boulinière, who proposed the most interesting and innovative reform project of the whole Republican period. Unfortunately, La Boulinière's plan arrived too late to be put into practice. ${ }^{13}$ Moreover, as late as 1802 , the Parisian government did not have a precise scholastic orientation, because the political context was very fluid and uncertain.

Botta, Brayda and Giraud planned an educational system for a wider section of the population and invited all parents to send their children to public schools. Funds for the university were increased, to make possible the opening of new faculties (among them the Faculty of Veterinary Science, functional to the demands of the French Army) and to increase the salaries of the teachers, not only at the university but at all school levels. Latin was eliminated from primary education and replaced by Italian; in the same way, religion was replaced by the study of the rights and duties of the citizen. Moreover, for the first time the normal teaching method, used in the schools of Habsburg Lombardy, was introduced in Piedmont and new textbooks were published, as charged by the government.

Every moment of public life was conceived as an occasion to win over the population to the Republican cause, or as an educational opportunity, functional to the construction of citizens aware of their rights and duties. Education assumed an explicit political meaning: for the Jury d'instruction publique and for all the republicans of the $27^{\text {th }}$ Military Division it was clear that Piedmont had been conquered by the Revolution and to convince their countrymen to follow the example of France it was necessary to explain the benefits and the rules of democracy.

In any case, resistance by the population was not lacking, because many parents distrusted a school without Latin and that was frequented without distinction by the children of all social classes. The enquiries of the time record the disappointment and concern of the government, which presided over the progressive emptying of classrooms despite the propaganda in favour of public schools.

Nevertheless, the projects formulated in those years and the concrete reforms in the organisation of the school, in didactics and in textbooks were important, because they were inspired by a new idea in education: no long a king's concession to an elite, but the acknowledgement of a right for all citizens. Moreover, the school represented the best way for the state to transmit to the younger part of the population its political, social and cultural ideals.

In fact, the Republican government had time only to promote a new idea of education, but not to build a new school model, even if it did indeed try to reform the school: between May 1799 and June 1800, the army of the Second Coalition ruled by the Russian general Suvorov occupied Turin and the larger part of the Savoyard state, cutting off all the reforms of the Republican Government. The plans made by the

\footnotetext{
${ }^{13}$ Archives Nationales de Paris, F/17/1603 Académie de Turin, Organisation de l'instruction publique en Piémont, 1800-1813, Rapport et projet d'arrêté sur l'instruction publique en Piémont, présenté à l'Administrateur général par $\mathrm{P}$. La Boulinière, chef de la division de l'intérieur, le $1^{\mathrm{er}}$ jour complémentaire an 9 (22 September 1801).
} 
Piedmontese counter-revolutionaries, during the short Austro-Russian occupation, demonstrated that a new way of viewing schooling and education had spread during the Republican period. For instance, the project proposed by Francesco Galeani Napione, a man whom we shall meet again in connection with the Restoration, suggested the extension of schooling to the humblest classes and introducing as a subject in primary schools something similar to the study of the rights and duties of the Republican schools. ${ }^{14}$

The opportunities to elaborate and to test new educational methods finished definitively a few years later, and precisely on 1 May $1802\left(11^{\text {th }}\right.$ floréal year X), when the 10 French parliament, following the wishes of the First Consul Napoleon Bonaparte, approved the Loi générale sur l'instruction publique. In the meantime, Piedmont had become a French region and for that reason it was obliged to adopt the laws made for the rest of the country.

The law provided for four different school levels: the petites écoles, or primary schools, paid for by the families and checked by the municipalities; the écoles secondaires, ruled by the towns under the supervision of the state; the lycées, which represented the intermediate level between the secondary schools and the universities, reserved for the best pupils; and at the top the écoles spéciales, the descendant of the faculties.

20 The law was based on an idea of education typical of the monarchies of the Ancien Régime: delegating literacy to the families and the municipalities, in reality it used the first school level as a way of limiting access to the upper levels, as well as an instrument of social control, excluding the lower classes from such education. For the first time, however, this choice was not only explained through a precise political strategy, but also through certain coherent pedagogic motivations, founded on the overcoming of the educational and social theories of the Enlightenment.

Introducing the new law to the Legislative Body, the director-general of instruction, Fourcroy, tried to demonstrate that if the "éducation des enfants et des jeunes gens" could seem "isolé de l'instruction", in reality education was granted because "dans des écoles bien organisées l'étude et la culture des lettres est un grand moyen de bonne éducation" moreover "le bon et l'entier emploi du temps, des occupations réglées qui le partageront tout entier, et surtout de bons exemples, des mœurs purs et douces dans les chefs: voila le véritable cours de morale qu'il faut faire suivre à la jeunesse". 15

35 It was the end of the idea of education as elaborated by the Enlightenment, which considered schooling as part of upbringing. Following this concept, the republican governments, in France as well as Italy, had introduced the study of the rights and the duties of the citizen, a sort of civic education ante-litteram into the programmes of primary schools, in order to provide the pupils with the possibility of participating in the life of the state. After the death of the Republic, the Consulate was interested in extinguishing the desire to participate in political life. For that reason, it needed to

\footnotetext{
$\overline{{ }^{14} \text { Archivio di Stato di Torino, Sezione Corte, Pubblica istruzione, Regia Università, mazzo } 3}$ di $1^{\circ}$ addizione Memoria intorno al modo di riordinare la Regia Università degli Studi, scritta nell'anno 1799 dal conte Galeani Napione di Coccolato, consigliere di Stato di S.M., incaricato delle incombenze di Regio Archivista di Corte.

${ }^{15}$ Recueil des lois et règlements concernant l'instruction publique, depuis l'édit de Henry IV en 1498 jusqu'à nos jours, vol. 2 (Paris: Brunot-Labbé, 1814), 55-84.
} 
return to the pre-revolutionary idea of education. But, at the same time, it could not assume that a new attitude towards the school and education had emerged.

It was necessary to found a new pedagogy and a new school, which rigorously separated education and upbringing, and was devoid of any political content. Since upbringing was considered a form of teaching strictly linked to morals, school was responsible for indoctrinating and transmitting useful notions to the pupils.

The Jury d'instruction publique supported the policies of Paris not because it considered the law of $11^{\text {th }}$ floréal year X a good law, but because it was convinced that Piedmont should indeed become a French region. Thus, Botta, Brayda and Giraud immediately proved to be ready to apply the law. The first act in this sense was to impose French as the official language of teaching, considering that it was the "langue de la vérité", as well as the idiom in which were written "les ouvrages immortels des philosophes, qui dans ces derniers tems ont ouvert une nouvelle route à l'esprit humain". 16

This attitude, so favourable to cultural annexation by France, created the void around the Jury: its enemies were not only the Republican leaders averse to the occupation, but above all the former heads of the Piedmontese school system, that is the university professors and the scholars who controlled the academies and the cultural institutions of the Savoyard Kingdom.

Until then the very moderate school reforms convinced more or less all of the Piedmontese republicans, who did not possess particularly deep knowledge in the educational field. It was not by chance that the only innovative reform proposal had been formulated by a foreigner: La Boulinière. However, the law of the 11 floréal year $\mathrm{X}$ had changed everything because it had been able to overturn not only the educational, but also the social and political systems. In these circumstances Piedmont needed a Jury determined to shelter its cultural institutions.

For that reason, whilst Bonaparte was replacing Jourdan with the conservative Joseph de Menou, at the beginning of 1803 the Jury was put on trial in Turin. It was not necessary to wait for the end of the trial (which finished some months later without any condemnation) to have a new Jury d'instruction publique. This was composed of three very well-known figures: Angelo Saluzzo di Monesiglio, who was one of the founders of the Academy of Sciences of Turin, Ottavio Falletti di Barolo, probably the richest man in the country, and Innocenzo Baudisson, one of the most representative professors at the university.

The decision was certainly approved by Napoleon, who had decided to govern the new provinces of the Empire through the local elites. ${ }^{17}$ With the dismissal of Jourdan and of the Jury the season of reforms and of the projects of renewal was closed. A new phase opened, characteriaed by the defence of the scholastic system of the Ancien Régime. The most evident paradox of that situation is that many of those literary men

\footnotetext{
$\overline{{ }^{16} \text { Raccolta delle leggi, provvidenze e manifesti emanati dai governi francese e provvisorio e }}$ dalla municipalità di Torino, unitamente alle lettere pastorali del citt. Arciv. di Torino (Turin: Davico, 1801-1802), 166.

${ }^{17}$ See Jean Tulard, Napoléon et la noblesse d'Empire (Paris: Tallandier, 1979); Rosalba Davico, "Peuple” et notables (1750-1816): Essais sur l'Ancien Régime et la Révolution en Piémont (Turin: Museo nazionale del Risorgimento, 1985); Gian Paolo Romagnani, "I gruppi dirigenti piemontesi tra monarchia sabauda e impero napoleonico (1780-1814)," in La Rivoluzione francese e il Risorgimento italiano, ed. Cristina Vernizzi (Turin: Silvestrelli \& Cappelletto, 1992).
} 
who rallied round the tradition, in conservative positions, in previous decades had persistently claimed that society needed to be enlightened.

It is viable, then, to believe that the adhesion to the Enlightenment of a consistent part of the Savoyard elites was limited to its scientific, literary and socialising elements, with the exclusion of its political messages. For these reasons, during the Revolution and the Napoleonic empire, they tenaciously defended the schooling model of the Ancien Régime.

The Piedmontese cultural and educational system was protected not only for its intrinsic value, but above all to defend the social and political model that had conceived it. A model that the former subjects of the Savoy dynasty quickly understood could be useful to Napoleonic France.

After the creation of the Empire, Napoleon Bonaparte imposed a common and centralised scholastic system aiming to use the school to transform the inhabitants of the new regions - including Piedmont - into French people: at school Latin was definitively replaced by French as the official language and Piedmont's pupils had to study French literature and history. At the same time, the primary schools were entrusted to the clergy, charged by the Emperor with the training of his subjects.

Nevertheless, the Piedmont school system managed to preserve some of its own peculiarities. This was partly made possible by the tenacity and the ability of its administrators, in particular Prospero Balbo, appointed by Napoleon rector of the University of Turin, but the Piedmontese school succeeded in reproducing itself above all because its organisation was borrowed by Bonaparte and extended to the entire empire. Of course, the reform of 17 March 1808, which created the Université impériale, had numerous sources. But the influence of the model of the university built by Victor Amadeus II is particularly evident in the power that the new law gave to the rector, charged, as the Magistrato della Riforma, not only with the training of teachers, but also with control over all the schools, from primary to university. ${ }^{18}$ This was clear to his contemporaries, and especially to the imperial inspectors Cuvier (Georges, the well-known geologist) and Coiffier, who wrote in a report sent to Paris that "c'est par l'Académie de Turin que l'empereur a fait le premier essai de son grand plan de réorganisation des études, et a préludé en quelque sorte à la création de l'Université impériale; il est à remarquer qu'elle appartenait autrefois à un système d'instruction très semblable en petit à celui de notre grand corps enseignant". ${ }^{19}$

\section{The Restoration and the counter-reformation of the school}

Less traumatic than might be imagined therefore was the return of the Piedmontese school system to the pre-revolutionary set-up, ratified by the collapse of the Napoleonic

\footnotetext{
${ }_{18}^{18}$ Alphonse Aulard, Napoléon Ier et le monopole universitaire. Origine et fonctionnement de l'Université (Paris: Armand Colin, 1911); Philippe Savoie, "Construire un système d'instruction publique. De la création des lycées au monopole renforcé (1802-1814)," in Napoléon et les lycées. Enseignement et société en Europe au début du XXe siècle, ed. J.-O. Boudon (Paris: Nouveau Monde Éditions-Fondation Napoléon, 2004), 39-55. See also Eugène Rendu, M. Ambroise Rendu et l'Université de France (Paris: Fouraut, 1861); Ambroise Rendu, Premier rapport aux observations sur le Discours de M. de Saint-Romain, concernant l'instruction publique et l'éducation (Paris: Nicolle, 1816).

${ }^{19}$ The Rapport of Cuvier and Coiffier was published in the Recueil des lois et règlements concernant l'instruction publique, depuis l'édit de Henry IV en 1498 jusqu'à nos jours, vol. 4 (Paris: Brunot-Labbé, 1820), 230-50.
} 
Empire and Savoy's reappropriation of its Kingdom in 1814. Very few things changed in school organisation during the French occupation, but 20 years had not passed in vain and what certainly had changed was the idea that the elites and the government had concerning the meaning of education and of instruction.

Nevertheless, when king Victor Emanuel I was restored his first goal was to forget the French occupation. Thus, following the examples of the past, he immediately closed the university and the College of the Provinces and Balbo was discharged, guilty of having collaborated with Bonaparte.

But even for the most attentive conservatives it was clear that the school was the best way to foster good citizenship: the history of the last decades had shown them the importance of education in the creation of loyal subjects useful to the country. The most convinced were Galeani Napione and Balbo. Galeani Napione, who had been named as a member of the Magistrato della Riforma, worked on a project of reform as from 1814. In 1818 it was again supported by Balbo, recalled to Piedmont from his duties as ambassador in Spain, with the purpose of leading the Magistrato della Riforma. Balbo and Galeani Napione made use of some valid assistants, and especially of Giuseppe Anselmi, a talented secondary school teacher and an expert on the European pedagogic debate.

The team led by Galeani Napione and Balbo worked on the substitution of Latin with Italian as a language for primary schools and, above all, on the distinction of two different careers for rich and poor students: the latter would limit their studies to Italian, taught in elementary schools, whilst the former would study Latin in the secondary schools. Another important point of their reform plan was the introduction of a sort of civic education, on the example of the French Revolution, based on the Catholic catechism and loyalty to the monarchy. ${ }^{20}$

Just when a definitive proposal for reform was ready, Turin, like other European cities, saw the outbreak of the revolutions of 1821, which directly involved many students of the university. Once again, the government closed the Athenaeum and the College of the Provinces. Balbo was permanently dismissed and Galeani Napione was silenced. At the same time also, the very few cooperative schools created in Piedmont under private initiative were outlawed and closed.

The Magistrato della Riforma was abolished and the leadership of the scholastic system entrusted to the ultra-conservative Giambattista Viotti, member of the Amicizia Cattolica. Besides this, the university and the College of the Provinces were closed for more than a year.

The Jesuits regained considerable influence, because they resumed the running of certain important colleges, but above all because Luigi Taparelli D'Azeglio, director of the Jesuit college of Novara and brother of the better known Massimo, writer and politician, was charged with the planning of a global project of reform of the educational system. The new law, issued in 1822 with the title of Regolamento per le scuole fuori dell'Università, did not expunge the educational system created during the French occupation, but tried to change it in a conservative way: for that reason, for the Piedmontese school in the 1820 s it is more correct to speak of a counter-reformation than of a simple restoration.

\footnotetext{
$\overline{{ }^{20} \text { The documents produced by the team led by Baldo and Galeani Napione are conserved in }}$ Archivio di Stato di Torino, Sezione Corte, Istruzione pubblica, Scuola per geometri e carte varie relative all'istruzione pubblica.
} 
The Regolamento invited all the municipalities to open primary schools in which it was compulsory to teach in Italian. This was the necessary requirement for the township to be allowed to possess higher schools, the only ones that in fact interested the elites. By then, literacy was considered also by conservatives as a tool for defence of the monarchy: a well-schooled people would have been able to defend itself against revolutionary propaganda. If before the French Revolution popular education in Piedmont was viewed with distrust and was neglected by the government and by the elites, with the Restoration it became the tool for the safeguard of power, both secular and religious. For that reason, contrary to Napoleon, Savoy gave much more attention to popular education and attempted to oblige all citizens to attend primary schools.

Moreover, Taparelli D’Azeglio recovered the projects of Balbo and Galeani Napione and arranged popular education as vocational instruction: training the lower classes in a job represented the only way to win over the secular fear of that part of the elites which considered school a danger for social stability. The introduction of Italian instead of French in primary schools, as well as the struggle over Latin, and the efforts for the employment of the Normal method with the intention of instructing larger portions of the population, on the revolutionary example, did not aim to build critical and aware citizens, but aimed at the transmission of civic, political and religious values suitable for the different social classes. While Latin and higher studies had to be reserved for the elites, the rest of the population was allowed only a short period of vocational instruction useful for the manual professions.

At the same time, the reform of 1822 gave much more power to the clergy, in fact repealing the law of 1729 . Certain important colleges were consigned again to the Jesuits and new religious orders were involved in the management of the schools. This was the case of the Institute of Brothers of the Christian Schools, which, before the Revolution, had never had permission to open schools in the Savoyard state. The brothers were charged with the running of primary schools in the capital in 1830, until then managed directly by the municipality.

Following the example of Napoleon, Savoy strengthened the control of the clergy over the schooling, but with different goals: Bonaparte was interested in the control of private education, managed for the most part by the religious orders; for Taparelli D'Azeglio, the clergy was the best guarantee of the morality of education. In that way, Piedmontese schools not only returned to 1798, but also abandoned the reforms undertaken in 1729 by Victor Amadeus II, who, the first in Europe, had wrested the educational system from the Church to submit it to the state.

\section{Origins of the paradox of popular education}

40 With the aim of making at least primary school compulsory, the Revolutionary Government already intended to foster citizens aware of their own rights and duties, to allow their integration into the new political system. And by including in the school programmes the teaching of civic education, the Revolution tried to involve the masses in its political project.

45 As under the Ancien Régime, the revolutionary schools had been conceived with propagandist goals, but the big difference was that they were intended to create, as we would say nowadays, inclusion and not exclusion, as the school system of the monarchy. At the same time, however, they were almost exclusively concerned with the social content of education, neglecting the aspect of the intimate and personal growth 
of the pupil. The idea of "public happiness" supplanted the right to happiness of the individual.

Not only did Napoleon take no interest in fostering citizens involved in the life of AQ4 the state, but neither did he concern himself with the diffusion of primary school. At the same time, however, the state increased its control over the school, especially in higher education, considered an important tool of social persuasion and proselytism. The Napoleonic Empire did not aim to form "the" citizen, but "a" citizen, obedient, sanctioned and ready to agree to the mission that society had prepared for him.

Savoy resumed from the point where Napoleon had stopped, adopting his idea of school: education was no longer conceived of as a concession granted by the king, as it had been before the Revolution, but it was not even a right. Rather it was considered by the government a duty or, at least, an opportunity granted to those subjects who accepted not to use education to modify their social status.

At the beginning of the nineteenth century, the idea of popular education promoted by the Enlightenment had lost its utopian message: since the French Revolution, governments conceived of school not as an instrument for laying the foundations for public and individual happiness, but as a tool for social stability and cohesion. This was the meaning of popular education that convinced modern states to make school compulsory.

For the first time, primary schools became obligatory, for the municipalities initially and then for the subjects. In the following centuries education would be considered a duty rather than a right.

As we know, their efforts to bring all the population to school were for a long time in vain. In my opinion, one reason was that they insisted on the obligation to respect a law made for the main utility of the state and they neglected the benefits that literacy has for individuals. For that reason, a large part of the society did not conceive of school as an opportunity, but as an undeserved interference of the state in the lives of families.

\section{AQ5 Notes on contributor}

